\title{
Ascaris suum in pigs of the Zona da Mata, Minas Gerais State, Brazil
}

\author{
Ascaris suum em suínos da Zona da Mata, Estado de Minas Gerais, Brasil \\ Mariana Costa Fausto ${ }^{1 *}$; Isabela de Castro Oliveira ${ }^{1}$; Guilherme Costa Fausto ${ }^{1}$; Lorendane Millena de Carvalho²; \\ Fabrício Luciani Valente²; Artur Kanadani Campos²; Jackson Victor de Araújo
}

${ }^{1}$ Departamento de Veterinária, Faculdade de Ciências Biológicas e da Saúde - UNIVIÇOSA, Viçosa, MG, Brasil

${ }^{2}$ Departamento de Veterinária, Universidade Federal de Viçosa - UFV, Viçosa, MG, Brasil

Received January 20, 2015

Accepted April 15, 2015

\begin{abstract}
Among the parasites that affect pigs, Ascaris suum stands out for causing the greatest losses to livestock production systems. This parasite can be monitored during the slaughter of animals through the identification of "milk spots" or white patches on the liver caused by its larval migration. However, infection in the herd is usually subclinical, which is why the presence of this parasite in industrial pig production has been overlooked. The aim of the study was therefore to evaluate the occurrence of milk spots on the liver of animals slaughtered in the micro-region of Ponte Nova in the Zona da Mata - Minas Gerais, Brazil, and to associate these lesions with the time of year, herd size and source of origin of the animals. An evaluation was made of 1,069 lots, totaling 108,073 animals, based on data extracted from the Federal Inspection Service. The animals were slaughtered during the period of January 2011 to June 2013. Out of the total number of slaughtered animals, 10,535 (9.75\%) tested positive for these lesions. Therefore, veterinarians and producers should be warned about the inefficiency of the deworming protocols that are used, and the need to develop and/or review control strategies for this parasite in production systems.
\end{abstract}

Keywords: Ascaris suum, control, liver, nematodes, deworming, pigs.

\section{Resumo}

Dentre os parasitas que acometem os suínos, Ascaris suum destaca-se como o mais impactante nos sistemas de criação. Seu monitoramento pode ser realizado durante o abate dos animais, por meio da identificação de "milk spots" ou manchas de leite presentes no fígado, decorrentes da sua migração larval. Entretanto devido ao fato da infecção ocorrer no rebanho normalmente de forma subclínica, a presença desse parasita na produção industrial de suínos vem sendo negligenciada. O objetivo do estudo foi avaliar a ocorrência de manchas de leite no fígado de animais abatidos na micro-região de Ponte Nova, na Zona da Mata de Minas Gerais - Brasil, e associar tais lesóes com a época do ano, tamanho do rebanho e local de origem dos animais. Foram avaliados 1.069 lotes, totalizando 108.073 animais. Os dados foram extraídos do Serviço de Inspeção Federal, e eram referentes aos animais abatidos, durante o período de janeiro de 2011 a junho de 2013. Do total de animais abatidos, 10.535 (9,75\%) foram positivos para a lesão. Portanto, veterinários e produtores devem ser alertados quanto à ineficiência dos protocolos de vermifugação utilizados e a necessidade do desenvolvimento e/ou revisão de estratégias de controle para este parasita na produção.

Palavras-chave: Ascaris suum, controle, fígado, nematoides, vermifugação, suínos.

Parasites that affect pigs are present in all production systems. Among them, Ascaris suum deserves special attention, both for its ability to survive in the environment in the form of embryonated eggs and for its zoonotic potential (SANCHEZ-VAZQUEZ et al., 2012).

*Corresponding author: Mariana Costa Fausto. Departamento de Veterinária, Faculdade de Ciências Biológicas e da Saúde - UNIVIÇOSA, Avenida Maria de Paula Santana, 3815, CEP 36570-000, Viçosa, MG, Brasil.

e-mail: maricfausto@gmail.com
The pigs are infected by the fecal-oral route, by ingestion of eggs containing third stage larvae $\left(\mathrm{L}_{3}\right)$, which are released into the small intestine, migrate to the liver, causing injuries commonly known as "milk spots". Then, $\mathrm{L}_{3}$ migrate to the lungs, reach the pharynx and is swallowed to reach the small intestine, where they are changed to $\mathrm{L}_{4}$ and $\mathrm{L}_{5}$, becoming adults around the 42th day post-infection. In this way, the pre patent period resulting from ingestion of infective eggs by pigs to egg production in female is 6 to 8 weeks (DIAS et al., 2011; NEJSUM et al., 2009; 
ROEPSTORFF et al., 1997). Work involving experimental infections have shown that $A$. suum can infect humans and can be considered a zoonosis (NEJSUM et al., 2012).

Although $A$. suum is usually not associated with clinical signs in pigs, the same can be found in the gastrointestinal tract during the inspection of animals, its presence has been associated, among other things, with low feed conversion, interference in the quality of post-vaccination immunity against various pathogens such as Mycoplasma hyopneumoniae, and economic losses due to the rejection of infected organs (ROEPSTORFF et al., 2011).

During the slaughter of these animals, livers with white patches called milk spots, which result from the larval migration of $A$. suum, are rejected as unfit for human consumption. This practice causes economic losses to the industry due to the disposal of the organ, a byproduct that adds value to the supply chain (MCGRAVIN \& ZACHARY, 2009; FRUET et al., 2013). However, although inspection during slaughter is considered important to verify the effectiveness of health programs implemented in swine production, its implementation has been increasing, mainly in European countries (ROEPSTORFF et al., 2011).

Due to losses in pig production, some countries have strict A. suum control and prevention programs. These programs are aimed at determining the prevalence and epidemiology of the parasite in the herd, based on the detection of milk spots on the liver of slaughtered animals (SANCHEZ-VAZQUEZ et al., 2010; BOES et al., 2010). The findings are systematically passed on to producers as a strategy to encourage control of the parasite in the herd (SANCHEZ-VAZQUEZ et al., 2012). In Brazil, although there is monitoring in slaughterhouses with federal oversight, there is no official program that requires this information be transferred to producers and veterinarians responsible for the animals. Thus, little is known about the prevalence and epidemiology of $A$. suum in the Brazilian herd.

In view of the above, the purpose of this study is to evaluate the occurrence of liver lesions described as milk spots, resulting from larval migration of Ascaris suum, in pigs slaughtered in the micro-region of Ponte Nova in the Zona da Mata-Minas Gerais, Brazil, associating these lesions with the time of year when they occur, and the size and location of the farms from which the animals originated.

The study was conducted based on data collected from the Brazilian Federal Inspection Service (SIF), pertaining to 1,069 lots, totaling 108,073 pigs slaughtered during the period of January 2011 to June 2013 in a commercial abattoir located in the municipality of Ponte Nova (1909'09” S latitude and 47040'29” W longitude), west of the Zona da Mata region of Minas Gerais. The animals came from 37 farms with intensive and technology-dependent production, distributed in 17 municipalities in the region. All the animals were of commercial lines, males (neutered) and females, with approximately $110 \mathrm{~kg}$ live weight. The farms were identified and classified as small (herd with up to 300 sows), medium (301 to 1000 sows) and large (herd with more than 1001 sows). During slaughter, the livers of all the animals were inspected according to the guidelines of RIISPOA, the Brazilian Sanitary and Industrial Inspection Regulation of Products of Animal Origin (BRASIL, 2001) and the fibrotic livers due parasite migration should be condemned. An analysis of variance (ANOVA) and the Kruskal-Wallis test were performed to identify correlations between the occurrence of the lesion and the time of year; the municipality of origin of the animals and the degree of infection; and the size of the herd and the degree of infection. The Dunn test was used for comparison between groups. The correlations were considered at a level of significance of 1 to $5 \%$. The data were analyzed using SigmaPlot software (version 11.0).

Among the 108,073 animals analyzed, 10,535 (9.75\%) tested positive for liver lesions (Table 1).

Monitoring during slaughter allows for fast and inexpensive evaluation of herd health (ČERNEK et al., 2012), which in turn allows for the estimation of economic losses based on the number of discarded organs and on the number of infected animals. Sanchez-Vazquez et al. (2010) recently demonstrated that infection by this parasite can decrease the animal's daily weight gain by up to $10 \%$, and the feed conversion of pigs by up to $13 \%$ in the growing phase and at slaughter. A high occurrence of the parasite has also been reported in the herds of several countries, such as Slovakia, England and Poland (ČERNEK et al., 2012; SANCHEZ-VAZQUEZ et al., 2012; KNECHT et al., 2012).

Two hundred and thirty-five (22\%) of the 1,069 lots of animals evaluated each had more than $20 \%$ of animals affected with this type of lesion. According to Sobestiansky et al. (2001) and Lippke et al. (2009), this finding is important, because the discovery of more than $20 \%$ of livers showing white spots during monitoring of the digestive tract is of epidemiological significance.

There was also a difference in the number of animals with liver lesions $(p<0.01)$ depending on the size of the farms from which they originated. Animals from larger farms (more than 1000 sows) had fewer livers rejected due to the presence of milk spots than animals from medium (301-1000 sows) and small (up to 300 sows) farms (Table1).

The lower rate of hepatic lesions in animals from larger farms may be related to their level of biosafety, since they are better protected from the sanitary standpoint. Larger operations are usually more technology oriented, have higher investments, and therefore better sanitation. Sanchez-Vazquez et al. (2010)

Table 1. Percentage of liver lesions (milk spots) caused by Ascaris suum, according to farm size, in the micro-region of Ponte Nova in the Zona da Mata - Minas Gerais State, Brazil, from January 2011 to June 2013.

\begin{tabular}{cccc}
\hline Farm size & Number of lots (\%) & Number of pigs evaluated & \multicolumn{1}{c}{ Positive pigs (\%) } \\
\hline Small (up to 300 sows) & $11(1 \%)$ & 765 & $81(10.58 \%)^{\mathrm{A}}$ \\
Medium (from 301 to 1000 sows) & $235(22 \%)$ & 17,573 & $3,534(20.11 \%)^{\mathrm{A}}$ \\
Large (more than 1001 sows) & $823(77 \%)$ & 89,735 & $6,920(7.71 \%)^{\mathrm{B}}$ \\
Total & 1,069 & 108,073 & $10,535(9.75 \%)$ \\
\hline
\end{tabular}

Numbers followed by different letters (A and B) in the column differ statistically $(\mathrm{p}<0.01)$. 
reported similar findings. These authors found that differences in the occurrence rate of the parasite are related to investments in veterinary care and in the implementation of sanitation, disinfection and deworming programs. Garcia \& Gonçalves (2012) also found that the larger the farm the higher its investment in production technologies. Thus, farms with larger numbers of sows tend to face fewer challenges since they are aided by these technologies.

Another relevant fact is that Brazilian farms classified as large have a higher in-house turnover rate because they produce their own breeding sows (IRGANG, 2002). Due to the introduction of fewer young animals, the introduction of infectious agents from outside the herd is also lower (GARDNER et al., 2002). As a consequence, the animals develop higher levels of immunity, reducing the prevalence of parasites such as $A$. suum in the herd, and of eggs of this parasite in the environment (JOACHIM et al., 2001; SANCHEZ-VAZQUEZ et al., 2010).

An analysis of the prevalence of $A$. suum by municipality also revealed differences $(\mathrm{p}<0.01)$. However, this difference can not be found. Evaluating absolute values, the municipality of Oratórios, followed by the municipality of Coimbra and Piranga, stood out for presenting the highest proportion of pigs with discarded livers (Table 2).

In the municipality of Oratórios, this fact can be explained by the high animal housing density; indeed, this municipality is considered a large swine producer in the region, and has a nearby slaughterhouse which is under federal inspection (Figure 1). In the municipality of Coimbra and Piranga, the lack of inspection, non-compliance with environmental regulations, and poor planning in the construction of farms, most of which are small and located close to urban areas, contributed to this result. According to Alayande \& Danmaigoro (2012), farms in subsistence creations located in the proximities of urban centers with poor sanitary health conditions for animals and man, are more prone to contamination by $A$. suum, since its eggs can survive and remain viable for up to

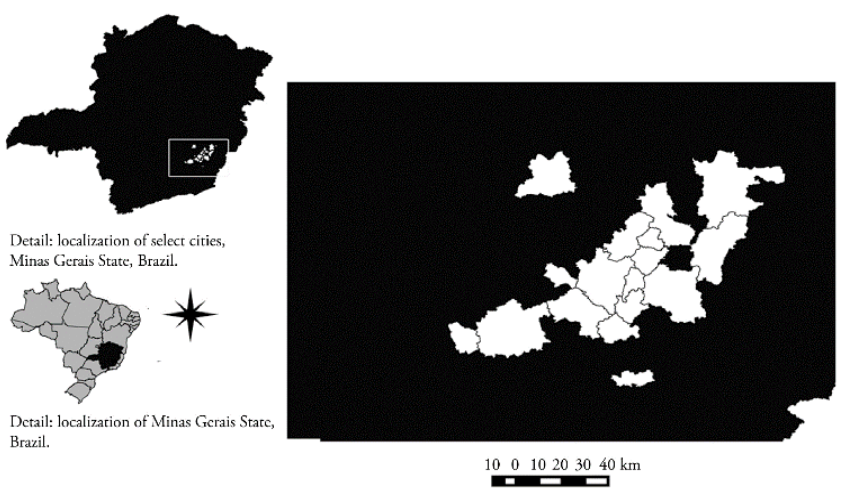

Figure 1. Map depicting the geographical position and municipalities where the pigs originated in the Zona da Mata region of Minas Gerais, Brazil, presenting milk spots in liver caused by migrating larvae of Ascaris suum, from Jan 2011 to Jun 2013.

five years in the environment. Moreover, according to the authors, A. suum is very similar to the species Ascaris lumbricoides, which infects humans. Leles et al. (2012) concluded that populations of Ascaris sp. that occur in humans and pigs have only minor adaptive changes in their phenotype and genotype, and a single natural history. Thus, $A$. suum is able to infect humans, which contributes to their persistence in the environment.

The transmission of $A$. suum in the pig population has been ascribed to several factors, including seasonality (SANCHEZ-VAZQUEZ et al., 2012). In this study, no difference was found between the two half-year periods under study $(\mathrm{p}=0.09)$. On other words, in the first period (January to June of each year analyzed), 5,887 (9.88\%) of the 59,526 animals evaluated tested positive for milk spots. In the second period (July to December), the number of positive animals was 4,642,

Table 2. Number of animals evaluated per municipality and percent of animals positive for milk spots in liver caused by migrating larvae of Ascaris suum in the micro-region of Ponte Nova in the Zona da Mata - Minas Gerais State, Brazil from January 2011 to June 2013.

\begin{tabular}{cccc}
\hline Municipality & Number of pigs evaluated & Number of positive pigs & $(\%)$ \\
\hline Abre Campo & 1,369 & 176 & 12.80 \\
Acaiaca & 60 & 1 & 1.70 \\
Amparo do Serra & 50 & 3 & 6.00 \\
Catas Altas da Noruega & 200 & 14 & 7.00 \\
Coimbra & 14,216 & 3,252 & 22.90 \\
Guaraciaba & 325 & 53 & 16.30 \\
Jequeri & 10,087 & 303 & 3.00 \\
Oratórios & 14,756 & 3,986 & 27.00 \\
Piedade de Ponte Nova & 3,965 & 126 & 3.17 \\
Piranga & 770 & 260 & 33.46 \\
Ponte Nova & 34,392 & 1,088 & 3.16 \\
Raul Soares & 917 & 38 & 4.14 \\
Rio Casca & 3,112 & 257 & 8.25 \\
Rio Piracicaba & 60 & 3 & 5.00 \\
Santa Cruz do Escalvado & 52 & 4 & 7.70 \\
Teixeiras & 4,337 & 480 & 11.0 \\
Urucânia & 19,405 & 491 & 2.53 \\
Total & 108,073 & 10,535 &
\end{tabular}


which represented $9.56 \%$ of the total number of evaluated animals (48,547 animals). This finding is in agreement with that reported by Dias et al. (2011). According to these authors, the climatic conditions inside and outside swine production facilities ensure the reinfection of animals, which is why deworming programs should be implemented intensively throughout the year. On the other hand, in countries with temperate climates, such as England, the occurrence of such lesions is concentrated in the second half of the year, coinciding with the summer and autumn seasons (JOACHIM et al., 2001). Therefore, since changes in climate may influence the development of the parasite's eggs in the environment, it is of paramount importance to understand the parasite's prevalence and epidemiology to ensure the success of measures adopted for its control (LAI et al., 2011).

The parasite $A$. suum is a persistent problem in swine herds located in the micro-region of Ponte Nova in the Zona da Mata region of the state of Minas Gerais, where it occurs continuously in subclinical form in pig production systems. However, this challenge is even greater at medium and small farms and in regions close to urban centers, and with higher animal housing densities. Thus, there is a need to gain a better understanding about the prevalence of this parasite in the herd and to reassess the deworming protocols that have been used. The implementation of monitoring programs during the slaughter of pigs, based on data from post-mortem inspections, has proved to be an effective and inexpensive tool that allows for improvements and modifications in control and prevention measures. Such programs should therefore be adopted not only in the region of this study but also in other regions of livestock production in the country, since they can contribute to the health of Brazilian swine herds.

\section{References}

Alayande MO, Danmaigoro A. Occurrence of "Milk Spot" due to Ascaris suum on liver of pigs slaughtered at Zuru, Nigeria. J Vet $A d v 2012$; 2(8): 430-433.

Boes J, Kanora A, Havn KT, Christiansen S, Vestergaard-Nielsen K, Jacobs J, et al. Effect of Ascaris suum infection on performance of fattening pigs. Vet Parasitol 2010; 172(3-4): 269-276. http://dx.doi.org/10.1016/j. vetpar.2010.05.007. PMid:20541323.

Brasil. Ministério da Agricultura, Pecuária e Abastecimento, Departamento de Inspeção de Produtos de Origem Animal - DIPOA, Divisão de Normas Técnicas. Regulamento de inspeção industrial e sanitária de produtos de origem animal. Brasil: Ministério da Agricultura, Pecuária e Abastecimento; 2001.

Černek AOL, Prokeš M, Ondrejka R, Hurníková Z, Takáčová D. Monitoring of Ascaris suum in slaughter pigs during 2000 - 2009 in. Slovakia. Helminthol 2012; 49(4): 221-224. http://dx.doi.org/10.2478/ s11687-012-0041-y.

Dias AS, Tanure AM, Manhães HGVC. Ocorrência de Ascaris suum em suínos abatidos na Zona da Mata, Minas Gerais. BrazJ Vet Res Anim Sci 2011; 48(2): 101-106.

Fruet APB, Scortegagna A, Fabricio EDA, Kirinus JK, Dörr AC, Nörnberg JL. Perdas econômicas por condenação de órgãos suínos em matadouros sob serviço de inspeção municipal. Rev Eletr Gest EducTecnol Amb 2013; 11(11): 2307-2312.
Garcia SK, Gonçalves JPM. Suinocultura mineira e sua defesa sanitária. Rev VZ Minas 2012; 114: 44-53.

Gardner IA, Willeberg P, Mousing J. Empirical and theoretical evidence for herd size as a risk factor for swine diseases. Anim Health Res Rev 2002; 3(1): 43-55. http://dx.doi.org/10.1079/AHRR200239 PMid:12400869.

Irgang R. Reposição de reprodutores suínos. BIRIBA'S Genética de Suinos - Boletim Técnico [online]. 2002 [cited 2014 Nov 19]; (1) Available from: http://www.sossuinos.com.br/Tecnicos/biribas/boltec01dez 2002.htm

Joachim A, Dülmer N, Daugschies A, Roepstorff A. Occurrence of helminths in pig fattening units with different management systems in Northern Germany. Vet Parasitol 2001; 96(2): 135-146. http://dx.doi. org/10.1016/S0304-4017(00)00431-3 PMid:11230920.

Knecht D, Jankowska A, Zaleśny G. The impact of gastrointestinal parasites infection on slaughter efficiency in pigs. Vet Parasitol 2012; 184(2-4): 291-297. http://dx.doi.org/10.1016/j.vetpar.2011.09.006. PMid:21955735.

Lai M, Zhou RQ, Huang HC, Hu SJ. Prevalence and risk factors associated with intestinal parasites in pigs in Chongqing, China. Res Vet Sci 2011; 91(3): e121-e124. http://dx.doi.org/10.1016/j.rvsc.2011.01.025. PMid:21349561.

Leles D, Gardner SL, Reinhard K, Iñiguez A, Araujo A. Are Ascaris lumbricoides and Ascaris suum a single species? Parasit Vectors 2012; 5(1): 42. http://dx.doi.org/10.1186/1756-3305-5-42. PMid:22348306.

Lippke RT, Kummer R, Marques BMFPPM, Mores TJ, Gonçalves MAD, Barcellos DESN. Monitora sanitária em suinocultura. Acta Sci Vet 2009; 37: 133-146.

Mcgravin MD, Zachary JF. Bases da patologia em veterinária. 4th ed. Brasil: Elsevier; 2009

Nejsum P, Betson M, Bendall RP, Thamsborg SM, Stothard JR. Assessing the zoonotic potential of Ascaris suum and Trichuris suis: looking to the future from an analysis of the past. J Helminthol 2012; 86(2): 148-155. http://dx.doi.org/10.1017/S0022149X12000193. PMid:22423595.

Nejsum P, Thamsborg SM, Petersen HH, Kringel H, Fredholm M, Roepstorff A. Population dynamics of Ascaris suum in trickle-infected pigs. J Parasitol 2009; 95(5): 1048-1053.http://dx.doi.org/10.1645/ GE-1987.1 PMid:19673589.

Roepstorff A, Eriksen L, Slotved HC, Nansen P. Experimental Ascaris suum infection in the pig: worm population kinetics following single inoculations with three doses of infective eggs. Parasitology 1997; 115(4): 443-452. http://dx.doi.org/10.1017/S0031182097001480. PMid:9364572.

Roepstorff A, Mejer H, Nejsum P, Thamsborg SM. Helminth parasites in pigs: new challenges in pig production and current research highlights. Vet Parasitol 2011; 180(1-2): 72-81. http://dx.doi.org/10.1016/j. vetpar.2011.05.029. PMid:21684689.

Sanchez-Vazquez MJ, Nielen M, Gunn GJ, Lewis FI. National monitoring of Ascaris suum related liver pathologies in English abattoirs: a time-series analysis, 2005-2010. Vet Parasitol 2012; 184(1): 83-87. http://dx.doi. org/10.1016/j.vetpar.2011.08.011. PMid:21889266.

Sanchez-Vazquez MJ, Smith RP, Kang S, Lewis F, Nielen M, Gunn GJ, et al. Identification of factors influencing the occurrence of milk spot livers in slaughtered pigs: A novel approach to understanding Ascaris suum epidemiology in British farmed pigs. Vet Parasitol 2010; 173(3-4): $271-$ 279. http://dx.doi.org/10.1016/j.vetpar.2010.06.029. PMid:20667659.

Sobestiansky J, Matos MPC, Souza CM. Monitoria patológica de suinos em matadouros. Goiânia: Gráfica Art; 2001. 